\title{
Physical Punishment at School in Three Educational Systems in Pakistan
}

\author{
Nazia Nazar \\ Developmental Psychology, Åbo Akademi University, Finland \\ nazia.nazar@abo.fi \\ Karin Österman \\ Developmental Psychology, Åbo Akademi University, Finland \\ karin.osterman@abo.fi \\ Kaj Björkqvist \\ Developmental Psychology, Åbo Akademi University, Finland \\ kaj.bjorkqvist@abo.fi
}

\begin{abstract}
A questionnaire was completed by I,I00 students (550 girls, mean age I3.3years, SD I.0; 550 boys, mean age I4.I, SD I.0) from three types of schools in Pakistan; Urdu medium, Elite English medium, and Madrassa. It includes scales measuring the frequency of victimization from physical punishment by a teacher, physical injuries from being punished by a teacher, negative feelings after physical punishment by a teacher, reasons for being punished by a teacher, and acceptance of physical punishment at school. Boys had significantly more often been victimized from physical punishment than girls, with boys from Madrassas being more often victimized than all other groups. Students from English medium schools scored significantly lower on all scales than students from the other schools. Girls reported a significantly more accepting attitude towards physical punishment at school than boys. Students from Urdu medium schools scored significantly highest on acceptance of physical punishment at school, while boys from English mediums schools reported the significantly lowest level of acceptance. For both girls and boys, acceptance of physical punishment at school was positively correlated with the other scales.
\end{abstract}

Keywords: physical punishment at school, acceptance, Pakistan, school systems.

Received I2 March 2019/Accepted I5 May 2019 @JEHCP All rights reserved

\section{Introduction}

By 2019, 54 countries worldwide had prohibited physical punishment towards children in all settings; still, only 10\% of all children are fully protected legally (Global Initiative to End All Corporal Punishment of Children, 2019). Even though Pakistan is a signatory to the United Nations Convention on the Rights of the child (UNCRC, 1989) physical punishment is practiced in educational institutions in the country. Article 89 of the Penal Code still 
provides a justification for practicing it against children in homes and at schools (Pakistan Penal Code, 1860). Incidents of physical punishment and severe injuries have been reported in the Pakistani media. In 2016, it was reported that a boy who was severely beaten by his teacher subsequently became paralyzed due to serious physical injuries to his head (Dawn, 2016). A year later, another boy was reported to have been beaten to death by two teachers (Dawn, 2017). Demographic and cultural factors have been associated with physical punishment. University students in Asia have been found to be more likely to endorse physical punishment than students in Europe (Douglas, 2006). The aim of the present study was to investigate victimization of students from physical punishment by teachers, and students' acceptance of it, in three types of schools in Pakistan; Urdu medium schools, English medium schools, and Madrassas. Sex differences regarding physical punishment were also investigated.

Studies from Western countries have shown boys to be more likely to be victimized from physical punishment at schools than girls (Brown, 2009; Delfabbro et al., 2006; Theoklitoua, Kabitsis \& Kabitsi, 2012; Youssef, Attia, \& Kamel, 1998), while girls have been found to be more self-disciplined (Duckworth \& Seligman, 2006). Several studies have indicated negative concomitants of physical punishment. Victimization from physical punishment has been associated with low self-esteem (Brezina, 1999; Flynn, 1994; Straus, 2003), depression (Turner \& Finkelhorn, 1996; Turner \& Muller, 2004), aggression (Becker \& Krug, 1964; Patterson, 1982; Radke-Yarrow, Campbell \& Burton, 1968; Steinmetz, 1979), violent behaviour among children (Straus, 1991), anxiety, delinquent behaviour (McCord, I99I), and alcohol abuse later in life (Fergusson \& Lynskey, 1997; MacMillan et al., 1999).

\section{Acceptance of Physical Punishment}

Victimization from physical punishment has been associated with accepting attitudes towards it (Buntain-Ricklefs, Kemper, Bell, \& Babonis, 1994; Clément \& Chamberland, 2014; Hyman, 1988; McAlister et al., 200I; Simons \& Wurtele, 20 I0; Vittrup, Holden, \& Buck, 2006). Family violence has been found to predict accepting attitudes towards physical punishment (Douglas, 2006). Laws banning physical punishment have been found to be associated with low levels of acceptance of physical punishment in a country (Gracia \& Herrero, 2008). A link has also been found between a legal ban and a decrease in physical punishment 
(Österman, Björkqvist, \& Wahlbeck, 20I4; Zolotor \& Puzia, 2010). According to one study, children became victims of physical punishment 1.7 times more often in countries where it was considered legal (duRivage et al., 2015).

The Educational System in Pakistan and Physical Punishment

The educational system in Pakistan is complex and divided into many different types of schools (Shamim, 2008). The three most common types are Urdu medium, English medium, and Madrassas, or religious seminaries. The Urdu medium educational system is largely government-run, and the language of instruction is Urdu. This type of school is characterized by rote learning and physical punishment (Rahman, 2004). A large number of English medium schools are run privately. The medium of instructions in these schools is English. Elite English medium schools are expensive and not affordable to the masses, while other schools cater for the education of the middle and lower class children (Shamim, 2008). In Pakistan, private schools generally yield better academic results than governmental schools (Aslam, 2009). The third type of schools, Madrassas, or religious schools, focuses mostly on imparting religious education (Rahman \& Bukhari, 2006).

According to a study conducted in Khyber Pakhtunkhwa, physical punishment was found to be common in disciplining children both in the homes and in the schools (Save the Children UNICEF, 2005). The study was based on data from 3,582 children between six and 14 years of age from public schools and Madrassas; it also included I,23I parents and 486 teachers. Around $43 \%$ of the students in the study who had been victimized from physical punishment were enrolled in public primary schools, $30 \%$ in public middle schools and $10 \%$ in public high schools, and $16 \%$ of the students were from private schools. The children reported 43 different types of punishment in schools, including hitting, kicking, hair and ear pulling, and insulting physical postures. As for the types of physical punishment, another study has reported that beating on the hands with a stick was considered common by $24 \%$ of the students, and $22 \%$ reported slapping the face or the head to be common (Plan Pakistan, 20I3).

Teachers in schools often consider physical punishment as a suitable mean to control aggressive behaviors in boys (Poole \& et al., 1991). Although it sometimes results in 
immediate compliance on the part of children, it has been found that it is not effective for moral internalization (Gershoff \& Bitensky, 2007). Furthermore, physical punishment has been shown to affect the student-teacher relationship negatively. Forceful and violent efforts by teachers aimed to control students' behavior in Western countries have been found to create negative feelings among students towards their teachers, and this, in turn, affects their learning (Brezina, 1999; Flynn, 1994; Richmond, 1990; Straus, 2003).

Although there is a scarcity of research in Pakistan on concomitants of victimization, both mild and severe physical punishment in Pakistani schools has been found to be negatively correlated with the students' motivation and learning (Ahmad, Said, \& Khan, 20I3). Another study from Pakistan showed that both mild and severe forms of physical punishment were associated with poor academic performance, learning problems, low class attendance, low creativity,lack of self-confidence, fear, depression, low self-esteem, pessimism, and feelings of inferiority (Naz, Khan, Daraz, Hussain, \& Khan, 20II). Furthermore, physical punishment has been found to be the most important reason for school drop-out in Pakistan (Ahmad et al., 20I4; Hussain, Salfi, \& Khan, 20I I; Naz et al., 20II).

In a study, 32 students were divided into two groups. Both groups were given physical punishment, but one was given psychological treatment after the punishment (Arif \& Rafi, 2007). The results showed that students who were punished lost their interest in their studies and their academic performance decreased, but students who received psychological treatment after punishment regained their interest in their studies.

Despite empirical evidence to the contrary, in a study, 20\% of Pakistani teachers completely agreed, and $31 \%$ partially agreed that physical punishment had no negative consequences for children, and $65 \%$ of the teachers also considered beating the students for violating school discipline to be necessary (Plan Pakistan, 2013).

The above studies indicate the prevalence and concomitants of physical punishment in schools in Pakistan, but levels of physical punishment in different types of schools in Pakistan have not been compared. Since the educational system is divided into different types of schools, the present study was designed to take this into consideration. Moreover, there is, 
in particular, a scarcity of research on physical punishment in the Madrassas, and no study so far has explored sex differences regarding victimization from physical punishment in schools in Pakistan.

\section{Method}

\section{Sample}

A questionnaire was completed by I, 100 students from three types of schools in Pakistan. The types of schools represented were Urdu medium (200 girls, 200 boys), Elite English medium (175 girls, I75 boys), and Madrassa (I75 girls, I75 boys). The age range of the participants was between II and I5 years of age, the mean age for girls being 13.3 years (SD I.0), and for boys I4.I (SD I.0). The age difference between girls and boys was significant $\left(t_{(1098)}=13.89, p<.001\right)$.

\section{Instrument}

The questionnaire included five scales measuring (a) frequency of victimisation from physical punishment by a teacher, (b) physical injuries from being punished by a teacher, (c) negative feelings after physical punishment by a teacher, (d) reasons for being punished by a teacher, and (e) acceptance of physical punishment at school. The items of the scales were selected based on the first author's experiences of the Pakistani school system. The response alternatives for the scales were on a five-point scale (for the first four scales: $0=$ never, $1=$ seldom, $2=$ sometimes, 3 = often, $4=$ very often, and for the last scale ranging from $0=$ strongly disagree to $4=$ strongly agree).

Frequency of victimization from physical punishment by a teacher was measured with the following II questions: (a) A teacher has beaten me, (b) I have been made to do sit-ups, (c) I have been given Murgha punishment (a stress position looping arms behind knees while holding ears), (d) I have been slapped, (e) I have been hit with a stick, (f) The teacher has thrown a book at me, (g) I have had to stand in a corner for a long time, (h) My fingers have been hit with an object, (i) I was forced to keep a pen between my fingers, (j) My hair was pulled, and (k) My ear was pulled. Cronbach's Alpha for the scale was $=.91$. 
The scale for measuring physical injuries from being punished by a teacher included the following six items: (a) pain, (b) cuts, (c) exhaustion, (d) fractures, (e) bleeding, (f) swelling. Cronbach's Alpha for the scale was .76.

Negative feelings after physical punishment by a teacher were measured with seven items: I felt (a) isolated, (b) embarrassed, (c) worthless, (d) angry, (e) scared, (f) shivering, (g) hatred for my teacher. Cronbach's Alpha for the scale was .84 .

Reasons for being punished by a teacher were measured with ten items: (a) I did not do my homework, (b) I forgot my lessons, (c) I got low grades, (d) I made noise in the class, (e) I disobeyed my teacher, (f) I came late to the class, (g) I misbehaved in the classroom, (h) I fought with my fellows, (i) The teacher dislikes me, and (j) I got punished for no reason. The response alternatives were on a five-point scale ( $0=$ never, $\mathrm{I}=$ seldom, $2=$ sometimes, $3=$ often, $4=$ very often $)$. Cronbach's Alpha for the scale was .86 .

Acceptance of physical punishment at school was measured with II items: a) Punishment is good for learning, b) It is ok to punish students who do not obey their teachers, c) Punishment should be allowed in schools, d) Punishment should be banned in the school, e) If I become a teacher I would punish my students, f) I obey my teachers after punishment, g) When I have been punished I forget my lesson, h) When I am physically punished I lose interest in the subject, i) When I am punished I can't concentrate on my studies, j) When I am punished I learn the lessons quickly, and k) I wish to leave school permanently because the teachers punish me. The items d, g, h, i, k were reversely scored. Cronbach's Alpha for the scale was .83.

\section{Procedure}

Paper-and-pencil questionnaires were distributed in 17 educational institutions in Lahore, the largest city, and the capital, of the Punjab province in Pakistan. The schools were Urdu medium public schools, English medium elite schools, and Madrassas. The schools were selected randomly from different posh and slum areas. The data were collected between December 2016 and April 2017. 


\section{Ethical Considerations}

The study was anonymous and was carried out in accordance with the principles concerning human research ethics of the Declaration of Helsinki (World Medical Association, 2013), and guidelines for the responsible conduct of research (Finnish Advisory Board on Research Integrity, 2012).

\section{Results}

Correlations between the Scales

All five scales of the study correlated significantly with all other scales (all $p<.00 \mathrm{I}$ ); this was the case for both girls and boys (Table I). It can be noted that acceptance of physical punishment at school was positively correlated with all the other scales for both girls and boys. The highest correlation for both girls and boys were found between physical injuries from being punished by a teacher and negative feelings after the punishment ( $r=.74$ vs. .63).

Table I

Correlations between the Scales in the Study ( $N=1$ I00), Girls above and Boys below the Diagonal

\begin{tabular}{lcccccc}
\hline & I. & 2. & 3. & 4. & 5. \\
\hline I. Victimisation from physical punishment by a teacher & - & $.64 * * *$ & $.67 * * *$ & $.67 * * *$ & $.24 * * *$ \\
2. Physical injuries from being punished by a teacher & $.61 * * *$ & - & $.74 * * *$ & $.59 * * *$ & $.24 * * *$ \\
3. Negative feelings after physical punishment by a teacher & $.63 * * *$ & $.67 * * *$ & - & $.67 * * *$ & $.27 * * *$ \\
4. Reasons for being punished by a teacher & $.61 * * *$ & $.52 * * *$ & $.55 * * *$ & - & $.31 * * *$ \\
5. Acceptance of physical punishment at school & $.31 * * *$ & $.36 * * *$ & $.44 * * *$ & $.34 * * *$ & - \\
\hline Note. $* * * p<.00 I$ & & & & &
\end{tabular}

Age

For girls, age correlated positively with physical injuries from physical punishment $(r=.17, p$ $<.00 \mathrm{I})$, negative feelings after the punishment $(r=.16, p<.00 \mathrm{I})$, and amount of reasons for physical punishment by a teacher $(r=.16, p<.001)$. Frequency of physical punishment and degree of acceptance of it did not correlate with age for girls. For boys, age was negatively correlated with acceptance of physical punishment at school $(r=-.13, p=.002)$ and negative 
feelings after physical punishment by a teacher $(-.12, p=.004)$. Frequency, reasons, and physical injuries did not correlate with age for boys.

\section{Forms of Physical Punishment}

The most common form of physical punishment by a teacher was slapping $(0.82)$, followed by beating $(0.78)$, hitting with a stick $(0.72)$, forced to stand in a corner $(0.6 \mathrm{I})$, being yelled at (0.47), and being thrown books at by the teacher $(0.41)$. Male teachers were found to use physical punishment significantly more often than female teachers $(0.54$ vs. 0.43$)\left[t_{(1098)}=\right.$ $2.89, p=.004]$.

Differences due to Sex and School Type

A multivariate analysis of variance (MANOVA) was conducted with sex and school type as independent variables and frequency of victimisation from physical punishment by a teacher, physical injuries from being punished by a teacher, negative feelings after physical punishment by a teacher, amount of reasons for being punished by a teacher, and acceptance of physical punishment at school as dependent variables. Age was kept as a covariate.

The multivariate test was significant for sex and school type and the interaction between them (Table 2 and Fig. I). The univariate tests revealed that boys had been significantly more often victimized from physical punishment than girls and that girls reported a significantly more accepting attitude towards physical punishment at school than boys. No significant difference was found between girls and boys regarding physical injuries from being punished by a teacher, negative feelings after physical punishment by a teacher, and the amount of reasons for being punished by a teacher.

The univariate tests were significant for school type regarding all five dependent variables. Scheffé's test revealed that students from English medium schools scored significantly lower on frequency of victimization from physical punishment by a teacher, physical injuries from being punished by a teacher, negative feelings after physical punishment by a teacher, reasons for being punished by a teacher, and acceptance of physical punishment at school than students from Urdu medium and Madrassas. Students from Urdu medium schools scored 
significantly higher on acceptance of physical punishment at school than students from Madrassas and English medium schools.

There was a significant interaction effect between sex and type of school for the frequency of victimization from physical punishment by a teacher and acceptance of physical punishment at school. Boys from Madrassas had been significantly most often victimized from physical punishment by a teacher, while boys from English mediums schools reported the lowest level of acceptance of physical punishment at school.

Table 2

Results of a Sex $x$ Type of School $(2 \times 3)$ Multivariate Analysis of Variance (MANOVA) with Five Scales as Dependent Variables $(N=1100)$

\begin{tabular}{|c|c|c|c|c|}
\hline & $F$ & $d f$ & $p<$ & $\eta_{p}^{2}$ \\
\hline \multicolumn{5}{|l|}{ Effect of Sex } \\
\hline Multivariate analysis & 8.67 & 5,1089 & .001 & .038 \\
\hline \multicolumn{5}{|l|}{ Univariate analyses } \\
\hline Victimization from physical punishment by a teacher & 10,77 & I, 1093 & .001 & .010 \\
\hline Physical injuries from being punished by a teacher & 0.62 & “ & ns & .001 \\
\hline Negative feelings after physical punishment by a teacher & 1.82 & “ & ns & .002 \\
\hline Reasons for being punished by a teacher & 2.85 & “ & .091 & .003 \\
\hline Acceptance of physical punishment at school & 15.16 & “ & .001 & .014 \\
\hline \multicolumn{5}{|l|}{ Effect of Type of School } \\
\hline Multivariate analysis & 40.95 & 10,2180 & .001 & .158 \\
\hline \multicolumn{5}{|l|}{ Univariate analyses } \\
\hline Victimization from physical punishment by a teacher & 60.85 & 2, 1093 & .001 & .100 \\
\hline Physical injuries from being punished by a teacher & 117.28 & “ & .001 & .177 \\
\hline Negative feelings after physical punishment by a teacher & 90.45 & “ & .001 & .142 \\
\hline Reasons for being punished by a teacher & 65.41 & “ & .001 & .107 \\
\hline Acceptance of physical punishment at school & 142.82 & “ & .001 & .207 \\
\hline \multicolumn{5}{|l|}{ Interaction between Sex and Type of School } \\
\hline Multivariate analysis & 9.89 & 10,2180 & .001 & .043 \\
\hline \multicolumn{5}{|l|}{ Univariate analyses } \\
\hline Victimization from physical punishment by a teacher & 16.86 & 2, 1093 & .001 & .030 \\
\hline Physical injuries from being punished by a teacher & 0.31 & “ & ns & .001 \\
\hline Negative feelings after physical punishment by a teacher & 0.87 & “ & ns & .002 \\
\hline Reasons for being punished by a teacher & 1.49 & “ & ns & .003 \\
\hline Acceptance of physical punishment at school & 14.03 & “ & .001 & .025 \\
\hline
\end{tabular}




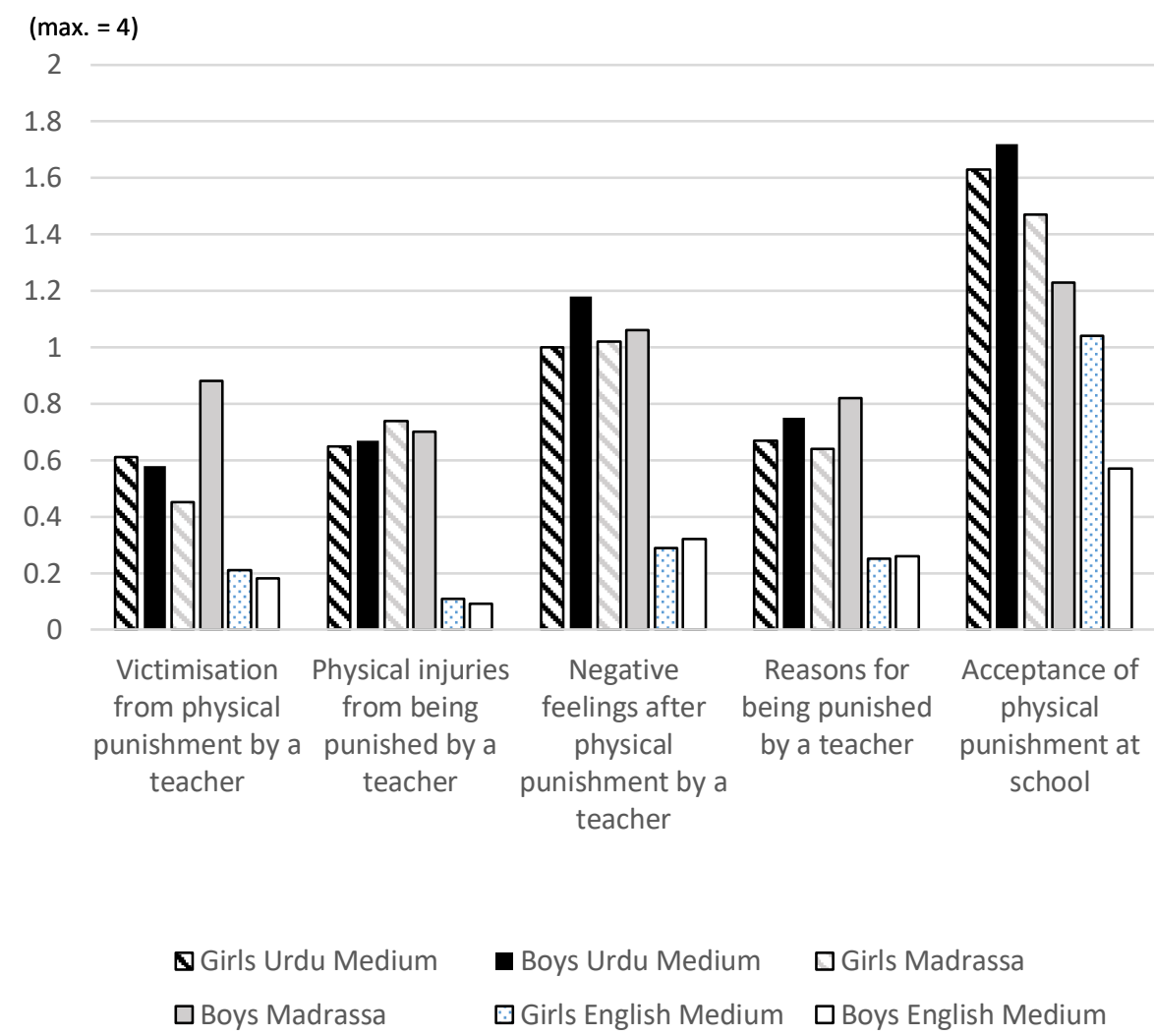

Figure I. Mean values for girls and boys from three educational systems in Pakistan on five scales $(N=1100)$.

\section{Discussion}

The purpose of the study was to investigate physical punishment by school teachers, and students' acceptance of it, in three types of schools in Pakistan. Students from English medium schools scored significantly lower than those from other school types on being victimized from physical punishment by teachers, receiving physical injuries from being punished by teachers, having negative feelings towards teachers after receiving physical punishment, perceived reasons for being punished by the teachers, and acceptance of physical punishment. This might be due to the fact that the elite English medium schools tend to adopt more humane learning techniques than Urdu medium schools (Rahman, 2005) and Madrassas. Similarly, in a previous study, students attending English medium schools 
exhibited more religious tolerance and gender equality, and lower bellicose attitudes towards India than students from Urdu medium schools and Madrassas (Nazar, Österman,\& Björkqvist, 2017). However, the elite English medium schools cater to the needs of a very small number of students in Pakistan.

Students from Urdu medium schools, the largest educational system in Pakistan, scored significantly highest on acceptance of physical punishment at school. This might be because Urdu medium schools are public schools, and the family background of these students might be different from students from other schools. For both girls and boys, acceptance of physical punishment was found to be positively correlated with the frequency of victimization, receiving physical injuries from being punished by teachers, and negative feelings towards teachers because of the punishment. The last-mentioned finding is in line with previous studies which show that the frequency of victimization from physical punishment is associated with its acceptance (Buntain-Ricklefs et al., 1994).

In the current study, boys from Madrassas were found to be more victimized than all other groups. Economic factors are likely to play an important role in this regard. Since the Madrassas provide free education, this is an opportunity for destitute parents to send their children to school. The low socioeconomic status of the parents might make Madrassa teachers likely to exhibit harsh authority towards the boys. The Madrassas have been accused of spreading religious intolerance, sectarianism, and violence (Leirvik, 2008). Hence, victimization from physical punishment at school may also trigger violence among students, as some studies have shown that frequent use of physical punishment creates aggression (Becker \& Krug 1964; Patterson, 1982; Radke-Yarrow et al.,1968; Steinmetz, 1979) and violent behavior among children (Straus, 1991). Students' victimization in Madrassas needs to be taken seriously as it might contribute to violence in Pakistan.

Boys had significantly more often been victimized from physical punishment than girls, which is consistent with a large body of research from different countries (Brown, 2009; Benbenishty, Zeira \& Astor, 2002; Delfabbro \& et al., 2006; Khoury-Kassabri, 2006; Theoklitouaet al., 2012; Youssef et al., 1998; Zeira, Astor, \& Benbenishty, 2002). This can be due to several reasons. It may be because boys are more prone to exhibit disturbing 
behavior (Skiba, Michael, Nardo, \& Peterson, 2002), including bullying (Boulton \& Underwood, 1992) and aggression (Parke \& Slaby, 1983), while girls are found to be more self-disciplined (Duckworth \& Seligman, 2006). Hence, teachers may use physical punishment as a mean to control aggressive behaviors in boys (Poole et al., 1991). The finding can also be explained in a cultural context; in many cultures, girls are considered to be weaker than boys, and it may also be prohibited for teachers to touch their bodies (Youssef et al., 1998). Boys, on the other hand, are expected to tolerate physical victimization better than girls because of their physical strength.

Notwithstanding, there can still be another possibility for this sex difference. Governmental schools in Pakistan are mostly gender segregated (Aslam, 2009). After the fifth grade, male teachers are responsible for teaching boys, while female teachers are assigned to teach girls in Urdu medium schools. So far as English medium schools are concerned, some schools are gender segregated while others are mixed schools. Madrassas are completely gender segregated in Pakistan. It is possible that boys are victimized more than girls because they are taught by male teachers. Previous research has shown that male teachers tend to resort to physical punishment to a greater extent than female teachers (Morrell, 200I). The current study also showed that male teachers used physical punishment more often than female teachers. Boys from Madrassas were found to be more often victimized than in all other groups.

Girls reported a significantly more accepting attitude towards physical punishment than boys. One reason for this fact might be that they were less exposed to physical punishment than boys. Since girls have been found to be more self-disciplined than boys (Duckworth \&Seligman, 2006), they might accept physical punishment in the classroom delivered in order to maintain discipline.

The highest correlation found for both girls and boys was between physical injuries from being punished by a teacher and negative feelings after the punishment. This indicates that physical punishment and physical injuries affect the student-teacher relationship negatively. This, in turn, may also affect learning in school. This finding is in line with that of another 
study, which found that teachers' aggressive attempts to control students' behavior created negative feelings among students towards their teachers (Richmond, 1990).

In the present study, the most common form of physical punishment by teachers was slapping, followed by beating, and hitting with a stick. The same was also found in a previous study from Pakistan (Plan Pakistan, 2013). It should be emphasized that all these forms sometimes lead to serious physical injuries and even endangering students' lives, as has been reported by the media (Dawn 2016; 2017).

\section{Limitations of the Study}

There are some limitations of the study which need to be taken into consideration. First, the data was drawn from one city, Lahore, in the Punjab district, and it is therefore not representative for the whole country. Also, the educational system in Pakistan is divided into many more sub-categories, while this sample included data only from the three major types of schools. Moreover, it should be noticed that the Madrassa sample in this study covers religious education in general, it does not show differences between specific sects of Islam. Furthermore, the age range of the participants was between II- and I5-years of age, and it did not include younger children or late-adolescents.

\section{Implications of the Study}

The current study provides empirical evidence of the prevalence of physical punishment and its acceptance among students. It raises questions on the monitoring system in the educational sector in Pakistan. Furthermore, the frequent victimization of students in the Madrassas challenges the credibility of religious, educational institutions, which are already under scrutiny due to the growing extremism, violence, intolerance, and sectarianism in the country (Leirvik, 2008). A study has shown that the level of physical punishment of children is associated with the prevalence of violence in society (Lansford \& Dodge, 2008). The findings of the study highlight the need for concrete accountability, monitoring, and surveillance of physical punishment in Pakistani schools. The study aims at being an impetus 
to create awareness among policymakers, educators, and the media, to repeal the laws which make physical punishment lawful in schools in Pakistan.

Acknowledgment

The study was supported by a grant from Högskolestiftelsen i Österbotten, Finland.

\section{References}

Ahmad, I., Said, H., \& Khan, F. (20I3). Effect of corporal punishment on students' motivation and classroom learning. Review of European Studies, 5, 130-134.

doi: $10.5539 /$ res.v5n4p 130

Ahmad, I., Said, H., Awang, Z., Yasin, M. A., Hassan, Z., Shafeq, S., \& Mansur, S. (20I4). Effect of self-efficacy on the relationship between corporal punishment and school dropout. Review of European Studies, 6, 196-200. doi:I0.5539/res.v6n I I 196

Arif, M. S., \& Rafi, M. S. (2007). Effects of corporal punishment and psychological treatment on students' learning and behavior. Journal of Theory and Practice in Education, 3, I7I180.

Aslam, M. (2009). The relative effectiveness of government and private schools in Pakistan: are girls worse off? Education Economics, 17, 329-354. doi: I0.1080/09645290903 | 42635

Becker, W. C., \& Krug, R. S. (1964). A circumplex model for social behavior in children. Child Development, 35, 37I-396. doi:I0.1037/0022-35I4.40.4.70I

Benbenishty, R., Zeira, A., \& Astor, R. A. (2002). Children's reports of emotional, physical, and sexual maltreatment by educational staff in Israel. Child Abuse \& Neglect, 26, 763-782. doi:I0.1016/S0I45-2I34(02)00350-2

Boulton, J. J., \& Underwood, K. (1992). Bully/victim problems among middle school children. British Journal of Educational Psychology, 62, 73-87. doi: I 0.1 I I I/j.2044-

8279.1992.tb01000.x

Brezina, T. (1999). Teenage violence towards parents as an adaptation to family. Youth and Society, 30, 4I6-444. doi:10.1 I77/0044II8X99030004002

Brown, B. (2009). Perceptions of student misconduct perceived respect for teachers, and support for corporal punishment among school teachers in South Korea: An exploratory case study. Educational Research for Policy and Practice, 8, 3-22. doi: 10.1007/s |067|-008-9059-9 
Buntain-Ricklefs, J. J., Kemper, K. J., Bell, M., \& Babonis, T. (1994). Punishments: What predicts adult approval. Child Abuse \& Neglect, 18, 945-955. doi:I0.10I6/S0 I452I34(05)80005-5

Clément, M. Ė., \& Chamberland, C. (20I4). Trends in corporal punishment and attitudes in favor of this practice: Toward a change in societal norms. Canadian Journal of Community Mental Health,33, I3-29, doi:I0.7870/cjcmh-20I4-0I3

Dawn. (2016, November 19). Teen paralyzed due to alleged torture by a teacher in Larkana. https://www.dawn.com/news/I 297235

Dawn. (20I7, May II). Boy tortured at school dies. https://www.dawn.com/news/I 332392

Delfabbro, P., Winefield, T., Trainor, S., Dollard, M., Anderson, S., Metzer, J., \& Hammarström, A. (2006). Peer and teacher bullying/victimization of South Australian secondary school students: Prevalence and psychosocial profiles. British Journal of Educational Psychology, 76, 7I-90. doi:I0.1348/000709904X24645

Douglas, E. M. (2006). Familial violence socialization in childhood and later life approval of corporal punishment: A cross-cultural perspective. American Journal of Orthopsychiatry, 76, 23-30. doi:10.1037/0002-9432.76.1.23

Duckworth, A. L., \& Seligman, M. (2006). Self-discipline gives girls the edge: Gender in selfdiscipline, grades, and achievement test scores. Journal of Educational Psychology, 98, 198-208. doi:10.1037/0022-0663.98.1.198

duRivage, N., Keyes, K., Leray, E., Pez, O., Bitfoi, A., Koç, C.,... Kovess-Masfety, V. (20I5). Parental use of corporal punishment in Europe: Intersection between public health and policy. PLoS ONE I0(2): e0I I8059. doi:I0.I37I/journal.pone.0I I8059

Fergusson, D. M., \& Lynskey, M. T. (I997). Physical punishment/maltreatment during childhood and adjustment in young adulthood. Child Abuse \& Neglect, 2I, 617-630. doi:I0.1016/S0I45-2I34(97)0002I-5

Finnish Advisory Board on Research Integrity. (2012). Responsible conduct of research and procedures for handling allegations of misconduct in Finland. Helsinki: Finnish Advisory Board on Research Integrity

Flynn, C. P. (1994). Regional differences in attitudes toward corporal punishment. Journal of Marriage and the Family, 56, 330-344. doi:10.2307/353102

Gershoff, E. T., \& Bitensky, S. H. (2007). The case against corporal punishment of children: Converging evidence from social science research and international human rights law and implications for US public policy. Psychology, Public Policy, and Law, I3, 23I-272. doi:10.1037/I076-897I.13.4.23।

Global Initiative to End All Corporal Punishment of Children. (2019). Global progress. https://endcorporalpunishment.org/countdown/ 
Gracia, E., \& Herrero, J. (2008). Is it considered violence? The acceptability of physical punishment of children in Europe. Journal of Marriage and Family,70, 210-2I7. doi: I0.I I I I/j. I74 I-3737.2007.00472.x

Hussain, A., Salfi, N. A., \& Khan, T. M. (20I I). Causes of students' dropout at primary level in Pakistan: An empirical study. International Journal of Humanities and Social Science, I, |43-15|.

Hyman, I. A. (1988). Eliminating corporal punishment in schools: Moving from advocacy research to policy implementation. Child Legal Rights, I5, I I0-II5.

Khoury-Kassabri, M. (2006). Student victimization by educational staff in Israel. Child Abuse \& Neglect, 30, 69I-707. doi:I0.1016/j.chiabu.2005.12.003

Lansford, J. E., \& Dodge, K. A. (2008). Cultural norms for adult corporal punishment of children and societal rates of endorsement and use of violence. Parenting, Science and Practice, 8, 257-270. doi:10.1080/I5295190802204843

Leirvik, O. (2008). Religion in school, interreligious relations, and citizenship: The case of Pakistan. British Journal of Religious Education, 30, 143-I54.

doi: $10.1080 / 0|4| 6200701831069$

MacMillan, H. L., Boyle, M. H., Wong, M. Y-. Y., Duku, E. K., Fleming, J. E., \& Walsh, C. A. (1999). Slapping and spanking in childhood and its association with the lifetime prevalence of psychiatric disorders in a general population sample. CMAJ, I6I, 805809.

McAlister, A., Sandström, P., Puska, P., Veijo, A., Chereches, R., \& Heidmets, L. T. (200I). Attitudes towards war, killing, and punishment of children among young people in Estonia, Finland, Romania, the Russian Federation, and the USA. Bulletin of the World Health Organization, 79, 382-387.

McCord, J. (199I). Questioning the value of punishment. Social Problems, 38, 190-200. doi: $10.2307 / 800527$

Morrell, R. (200I). Corporal punishment and masculinity in South African schools. Men and Masculinities, 4, I40-I57. doi:I0.1 I77/I097I84X01004002003

Naz, A., Khan, W., Daraz, U., Hussain, M., \& Khan, Q. (20I I). The impacts of corporal punishment on students' academic performance/career and personality development up-to secondary level education in Khyber Pakhtunkhwa Pakistan. International Journal of Business and Social Science, 2, I30-140.

Nazar, N., Österman, K., \& Björkqvist, K. (20I7). Religious tolerance, gender equality, and bellicose attitudes: A comparative study of three educational systems in Pakistan. European Journal of Social Sciences, Education and Research II, I26-I35. doi:I0.264I7/ejser.vl Iil.pI26-I35 
Österman, K., Björkqvist, K., \& Wahlbeck, K. (20I4). Twenty-eight years after the complete ban on the physical punishment of children in Finland: Trends and psychosocial concomitants. Aggressive Behavior, 40, 568-58I. doi:I0.1002/ab.2I537

Pakistan Penal Code. (1860). Pakistan Penal Code (Act XLV of I860). http://www.pakistani.org/pakistan/legislation//860/actXLVof I860.html

Parke, R. D., \& Slaby, R. G. ( 1983$)$. The development of aggression. In E. M. Hetherington (Ed.), 4: Socialization, personality, and social development (pp. 547-64I). New York: Wiley.

Patterson, G. R. (1982). Coercive family process. Eugene, OR: Castalia.

Plan Pakistan. (2013). Stopping the fear: Why teachers use corporal punishment. Islamabad Pakistan: Plan Pakistan.

Poole, S. R., Ushkow, M. C., Nader, P. R., Bradford, B. J., Asbury, J. R., Worthington, D. C., Sanabria, K. E., \& Carruth, T. (199I). The role of the pediatrician in abolishing corporal punishment in schools. Pediatrics, 88, 162-167.

Radke-Yarrow, M. R., Campbell, J. D., \& Burton, R. V. (1968). Childrearing: An inquiry into research and methods. San Francisco: Jossey-Bass.

Rahman, K., \& Bukhari, S. R. (2006). Pakistan: Religious education and institutions. The Muslim World, 96, 323-339.

Rahman, T. (2004). Denizens of alien worlds: A survey of students and teachers at Pakistan's Urdu and English language-medium schools, and madrassas. Contemporary South Asia, 13, 307-326. doi:10.1080/09584930420002722 I2

Rahman, T. (2005). Passports to privilege: The English-medium schools in Pakistan. Peace and Democracy in South Asia, I, 24-44.

Richmond, V. P. (1990). Communication in the classroom: Power and motivation. Communication Education, 39, I8I-195. doi:I0.1080/0363452900937880 I

Save the Children \& UNICEF. (2005). Disciplining the child: Practices and impacts, NWFP: Schools and Literacy Department.

Shamim, F. (2008). Trends, issues, and challenges in English language education in Pakistan. Asia Pacific Journal of Education, 28, 235-249. doi: I 0. 1080/02 I88790802267324

Simons, D. A., \& Wurtele, S. K. (2010). Relationships between parents' use of corporal punishment and their children's endorsement of spanking and hitting other children. Child Abuse \& Neglect. 34, 639-46. doi:10.1016/j.chiabu.2010.01.012

Skiba, R. J., Michael, R. S., Nardo, A. C., \& Peterson, R. L. (2002). The color of discipline: Sources of racial and gender disproportionality in school punishment. The Urban Review, 34, 317-342. doi:10.1023/A:1021320817372 
Steinmetz, S. K. (1979). Disciplinary techniques and their relationship to aggressiveness, dependency, and conscience. In W. R. Burr, R. Hill, F. I. Nye, \& I. L. Reiss (Eds.), Contemporary theories about the family: Vol. I Research-based theories (pp. 405-438). New York: Free Press.

Straus, M. A. (199I). Discipline and deviance: Physical punishment of children and violence and other crime in adulthood. Social Problems, 38, I33-154. doi:10.2307/800524

Straus, M. A. (2003). The primordial violence: Corporal punishment by parents, cognitive development, and crime. Walnut Creek, CA: AltaMira.

Theoklitoua, D., Kabitsis, N., \& Kabitsi, A. (20I2). Physical and emotional abuse of primary school children by teachers. Child Abuse \& Neglect, 36, 64-70.

doi:I0.1016/j.chiabu.20II.05.007

Turner, H. A., \& Finkelhorn, D. (1996). Corporal punishment as a stressor among youth. Journal of Marriage and the Family, 58, I55-166. doi: 10.2307/353384

Turner, H. A., \& Muller, P. A. (2004). Long-term effects of child physical punishment on depressive symptoms in young adults: Potential moderators and mediators. Journal of Family Issues, 25, 76 I-782.doi: I 0.I I77/0 I 925 I 3x032583 I3

UNCRC, United Nations Convention on the Rights of the Child. (1989). United Nations Treaty Collections.

https://treaties.un.org/Pages/ViewDetails.aspx?src=IND\&mtdsg_no=IV-

I I \&chapter=4\&lang=en

Vittrup, B., Holden, G. W., \& Buck, J. (2006). Attitudes predict the use of physical punishment: A prospective study of the emergence of disciplinary practices.

Pediatrics, I I 7, 2055-2064. doi:I0.I542/peds.2005-220

World Medical Association. (20I3). Declaration of Helsinki: Ethical principles for medical research involving human subjects. JAMA, 310, 2191-2194.

doi:10.1001/jama.2013.281053

Youssef, R. M., Attia, M. S., \& Kamel, M. I. (1998). Children experiencing violence. II. Prevalence and determinants of corporal punishment in schools. Child Abuse \& Neglect, 22, 975-985. doi:I0.10I6/SOI45-2I34(98)00084-2

Zeira, A., Astor, R. A., \& Benbenishty, R. (2002). Sexual harassment in Jewish and Arab public schools in Israel. Child Abuse \& Neglect, 26, I49-166. doi:I0.1016/S0 I452I34(0I)003 |4-3

Zolotor, A. J., \& Puzia, M. E. (2010). Bans against corporal punishment: A systematic review of the laws, changes in attitudes, and behaviors. Child Abuse Review, 19, 229-247. doi: I0.1002/car.II3I 